\title{
Parental choice and the rural primary school: lifestyle, locality and loyalty
}

MARION WALKER* AND GORDON CLARK

Lancaster Environment Centre, Lancaster University, Lancaster, LA1 4YQ, UK.

*Corresponding author. Email: marion.walker@lancaster.ac.uk 


\title{
Parental choice and the rural primary school: lifestyle, locality and loyalty
}

\begin{abstract}
This paper discusses the geography of parental choice in a rural locale and shows how a group of parents negotiated their way through the process of primary school choice. Using ethnographic data collected through interviews and observations with parents and staff from three rural primary schools in England, the research utilises Bourdieu's concepts of capital, habitus and field to show how the resources and values the parents held affected the school choices they made. The paper demonstrates that the longerterm resident local parents were influenced not only by their cultural capital but also by familial ties and an emotional commitment to the rural locale and these parents were therefore more inclined to support their local school. In contrast, the more recent newcomer parents used their cultural capital and spatial power to shop around to find what they believed to be the 'right' school. The paper argues that the newcomer parents had less allegiance to place and hence to the symbolic position that the school holds within the rural community within which they lived.
\end{abstract}

KEYWORDS: geography of education; parental choice; rural migration; Bourdieu's theory; spatial power; social reproduction 


\section{Introduction}

Like all English schools since the 1988 Education Reform Act (ERA), rural primary schools have been subject to government policies aimed at raising education standards through the marketisation of education and the institution of parental choice mechanisms (DfE, 1992). However, the effect the market is having on rural primary schools and their parent consumers is under-researched. The parental choice literature has focused predominantly on choice in urban areas (Goldring and Hausmann, 1999) and, with the exception of Vincent et al.'s (2004) research within the pre-school sector, the focus has been on choice within the secondary sector (Crozier et al., 2008; Le Grand, 1991a; Reay, 1996; Reay and Lucey, 2000; Taylor, 2001a; 2001b; 2002; Willms and Echols, 1992). This paper begins to address the gap in the literature by demonstrating the complexities of primary-school choice for parents living in a rural county in England.

Traditionally English primary schools have acted as 'feeder' schools to secondary schools and, for some parents, choice in the primary sector is the first step towards securing a place at their preferred secondary school. Moreover, these are the middleclass 'skilled' parent choosers, Gewirtz et al. (1995) suggest, who think in the longterm so that 'choice of primary school is often the first of several strategic decisions involved in the careful construction of their children's school career' (Gewirtz et al., 1995, p.26). Extending this work, more recent studies by educational sociologists (Ball et al., 2004; Ball and Vincent, 2005; Vincent et al., 2004) have gone on to show the ways in which 'middle-class educational strategies are constructed from a very early age' (Ball et al., 2004, p. 478). Parental choice within the pre-school sector 
socially positions children thus affecting their long-term educational careers (Vincent et al., 2004). Working from the premise that 'distinctive areas... reflect the 'lifestyle' differences within the middle-class' (Butler and Robson, 2003, cited in Vincent et al., 2004, p.233) Vincent et al. argue for a 'more flexible approach' to the process of parental choice by considering the link between social class, lifestyle and locality. In contrast, McDowell et al.'s (2006) research into the choices that urban middle-class households make about childcare shows that 'place is not a static, bounded container for social relations but is instead the coincidence of a range of interconnected social processes operating at different scales over different time-periods' (McDowell et al., 2006, p.2163). McDowell et al. (2006, p.2179) go on to suggest that 'the significance of place for the middle class may be in decline'. In this paper we consider the significance of place for the parents negotiating primary school choice in a rural locale.

By drawing on the parental choice literature from educational sociology and from the emerging geographies of education literature (Butler and Hamnett, 2007; Butler and Robson, 2003; Gulson and Symes, 2007; Warrington, 2005), this paper offers an insight into how 'thinking through education' (Hanson Thiem, 2008, p.1) can inform critical geographic thought by illuminating the dynamics of spatial power and cultural capital through the process of parental choice. The paper considers the choice process for the parents at three rural primary schools that are in close geographic proximity; each school is approximately three miles away from the other two schools. The parents include those who are long-term rural residents, and for the purposes of this paper we refer to them as the 'locals', whereas the parents who have moved into the area more recently we refer to as the 'newcomers'. The schools are situated in an 
affluent area and locally have good reputations. The study sets out to uncover why parents see one primary school as 'superior' to another, and why some parents would choose to send their child to a school other than their nearest when doing so incurs extra time and travel costs. The paper argues that the newcomer parents have less allegiance to place and hence to the symbolic position that the school holds within the rural community. As a consequence the newcomers are more likely to shop around than the locals to find what they believe to be the 'right' school. Sometimes this will be the same school as the locals chose (but chosen for different reasons) and sometimes it will be a different school.

\section{Social class, resources and lifestyle}

Existing empirical research shows that finding the 'right' school is a complex process dictated by family and structural limitations (Ball, 1993; 2003; Reay, 1996; Reay and Lucey, 2000). Choice is affected, on the one hand, by the range and number of resources parents have at their disposal (Vincent, 2001), and on the other, by the values they uphold (Francis and Archer, 2005; Vincent, 2001). The education literature shows that in the secondary sector parents (and pupils) are influenced by academic success (Bradley et al., 2000; 2001), evidenced by league tables and Office for Standards in Education (Ofsted) reports, by local rumour and reputation (Ball and Vincent, 1998), travel distance to school and ties with the locale (Crozier et al., 2008; Gewirtz et al., 1995; Reay and Lucey, 2000). Although, the discourse of choice suggests that equal opportunities are open to all (Le Grand, 1991b), research shows that parental choice is governed by a number of structural, social and economic constraints and that the process is linked to social class positioning, resources and lifestyle. The neo-liberal concept of choice (DfE, 1992) is presented to parents as a 
'good thing' but as Ball points out (1993, p.9) 'parents can express a choice' but it does not necessarily mean they will get that choice.

More choice is available to those with the skills and the resources to work the system to best advantage but the early literature polarised the process of parental choice between inertia and pro-activity referring to the parents as 'alert' and 'inactive' (Willms and Echols, 1992) or 'disconnected' working-class choosers and semi-skilled and skilled' middle-class choosers (Gewirtz et al., 1995). In broad terms the school choice process is very different for middle-class and working-class parents but both Vincent's (2001) and Warrington's (2005) research show that it is important to take a more nuanced approach to parental choice to take account of the fractions within classes. Vincent (2001) makes a distinction between the middle-class parents who work in the public sector (in education or other 'caring' professions) and the middleclass parents who have worked their way up to supervisory and managerial posts in the private sector. She notes that the 'education-insider' professional parents are the ones who rely upon 'their cultural capital as a key asset [in] helping them to identify and manage their children's chances of reproduction within the middle-classes' (2001, p.356). In stark contrast to this, Warrington (2005) shows that, in spite of the educational aspirations working-class parents may have for their children, for parents who live in areas of social deprivation the social and spatial inequalities they experience negates their cultural capital.

Indeed, as Massey (1995) points out, the middle-classes are more spatially mobile than the working-classes and therefore have more spatial power. Although the theorisation of rural gentrification is under researched (Smith and Higley, 2008) 
Butler (1997) shows, through his research on urban gentrification, how school choice is one way in which the middle classes can utilise their power, using solutions such as moving house or long-distance commuting 'to ensure that their children get the best of what is available' (Butler, 1997, p.164). Nevertheless, contemporary social-class analysis shows that the rigid class divisions of working and middle-class are no longer flexible enough to cope with the complexity and diversity of rural family life (Cloke and Thrift, 1990; Urry, 1995; Savage, 2000).

\subsection{Choice and the market: working with Bourdieu}

The qualitative research has therefore focussed on the types of resources parents have, such as the time and economic cost involved in choosing a school other than a local one or the ways in which some parents prioritise criteria such as school ethos above academic reputation (Reay et al., 2007). In explaining this situation many authors have found Bourdieu's relational concepts of capital, habitus and field useful and we now go on to explain why these concepts are central to the framework for this study.

Our research raises issues about the structures at play and the degree of power parents have to operationalise the mechanism of school choice to best advantage. In order, therefore, to link the structure with the people we adopt a structure-agency framework derived from Bourdieu and suggest that this approach enables 'a stratified view of the “subject" whose different properties and powers emerge at each level' (Archer, 2000, p.254). Essentially the concepts of capital, habitus and field were designed for use as empirical flexible tools, and as Maher (1990, p.21) points out, they offer 'a method, directed towards the analysis of social and economic practice, firmly anchored in ethnographic research'. Within education, researchers continue to draw upon 
Bourdieu's work because of its theoretical relevance to education linked especially to pupil achievement levels and differing parental aspirations (Gewirtz et al., 1995; Reay, 1995a; 1995b; 1996; 2004; Francis and Archer, 2005; Archer and Francis, 2006). Capital enables people to take up a position, which then interacts with their habitus within the field of social practice; so that for example in the field of education, parents possess various forms of capital, and this interacts with their habitus (or disposition) resulting in school preference for a school with particular characteristics ranging from faith-based, to size, ethos or academic status. Within his book Distinction, Bourdieu (1984, p.1) suggests that cultural practices and tastes, which include level of education can be used as markers of social class so that connections can be made between class advantage and educational knowledge through the concept of cultural capital.

It is important, however, to note that the three conceptual tools are in fact relational $([$ (habitus $)($ capital $)]+$ field $=$ practice $($ Bourdieu, 1984, p.101) and were not intended to be used in isolation. Understandings of choice must therefore be considered not only in relation to access to capital but also to the embodied and internalised concept of habitus (Bourdieu, 1977). Habitus, Dovey (2005, p.284) explains, 'is a way of knowing the world' and as Reay (1996, p.581) points out, habitus affects the connections parents make with 'localised issues of history and geography' thus providing the context for the individual choice-making process. Economic and cultural capitals interact with personal habitus to shape the spatial framework within which parents operate (Reay, 1996). 
In this paper we draw on the concepts to illustrate the ways in which capital and habitus affect parents making school choices in a rural context. Bourdieu's work often focuses on conflict and in this paper we studied particularly the conflicts parents have from various pressures on them when choosing a school. The ideal school nearest and in all respects best - may not exist; we study how parents resolve these conflicts. The pervasive surplus of rural primary school places in our county means that conflict among parents for scarce places at over-subscribed schools does not occur. With this in mind we now turn to the relevance of this discussion with respect to parental choice in a rural county in northern England.

\section{Methodology}

This study considered the complex interactions between three schools and their parent consumers within the context of the rural educational market place and therefore required a methodology that allowed us to 'engage with' rather than 'ignore' those complexities (Limb and Dwyer, 2001, p.2). In order to study real people in real situations we therefore chose a mixed-method qualitative approach to include in-depth interviews, non-participant observations and analysis of secondary data.

The research draws on data collected at three rural primary schools during the summer and autumn school terms of 2004; analysis of the county and school Ofsted reports and school prospectuses; a week of observations in each school collecting detailed field notes; and 34 semi-structured interviews with county council employees, staff, governors and parents. The interviews lasted between one and one and a half hours, all were transcribed and analysed, and a sub-set is displayed here as quotations. The 
names of the schools, participants and all the places discussed in this paper are pseudonyms.

Insert Table 1 here: Parent Participants

Insert Table 2 here: Teacher and County Council Participants

The county has a low-density population and a high proportion of primary schools with a hundred or fewer pupils (Ofsted, 2001a). Given that the three schools are perilously close to or under the 50-pupil threshold that the county uses to classify schools as 'very small' all three schools are vulnerable to closure in a county that has surplus primary school places (Defra, 2004). The schools work in a cluster with three others, sharing facilities and resources and they apply for funding specifically targeted towards small schools that are prepared to work in collaboration with similarly sized schools (Ribchester and Edwards, 1999; Williams, 2008). Yet the reality is that the schools are operating in what Taylor (2002, p.199) refers to as 'a local competitive arena'. The three schools have surplus places and need to compete with their neighbours for pupils so that school choice in this context is real for parents. This is not a situation where there are more pupils than there are school places. The Local Authority uses the system of catchment and out-of-catchment, and because of this we refer to this categorisation to differentiate between those pupils who attend their nearest (catchment) school and those who do not. However, the system (used in other counties) of a geographical boundary i.e. a catchment area, to ensure that pupils are 
distributed between schools, does not come into play in this county where surplus places are endemic.

The county is characterised by pockets of affluence and deprivation (Ofsted, 2001a) and the three schools in our study are situated in relatively affluent villages. However, approximately 3 miles from Greenthwaite is the village of Lowdale; an industrial village with a highly transient population and a large Local Authority housing estate. At the time of data collection Lowdale Community School, had a pupil roll of 80 and was designated as a Sure Start school providing extra resources to local families and pupils. None of the pupils in our three schools travelled from Lowdale village, and no one from our study area was known to send their child to Lowdale School. Fieldsend headteacher Alison believed that the working-class parents in Lowdale did not have realisable school choice and she said, 'one or two parents in Lowdale wanted to send their children here but even if they have a car well, they don't always have the money for petrol'. The contrast between Lowdale and the other three schools highlights the connection for parents between class, resources and choice.

Insert Table 3 here: The Schools 


\subsection{Fieldsend Church of England Voluntary Controlled ${ }^{1}$ School}

Fieldsend School is an infant and junior school catering for 4-11 year olds. The children are divided into three classes. Pupil attainment on entry is 'around the national average' (Ofsted, 2000a). The school has three classrooms, a hall, staff room/library, office, playground, playing fields and a garden. The school is close to the village green with its cluster of cottages, converted barns and parish church. The village has some new houses including some 'affordable homes' and a range of services including a pub, hotel, garage, hall, children's play area, nursery and medical centre. The school building dates back to the late nineteenth century and has undergone various extensions to provide more facilities but has kept a number of original features that maintain its historical identity.

Fieldsend School was named nationally as a 'Successful School' and hence has a local reputation for being a 'good' school. Alison, the headteacher, says this resulted in the school being sought after by parents of children who would not be eligible for a Statement of Special Needs, 'children who really don't get any funding but are struggling'. The school is now known locally for its positive approach and caring ethos and many interviewees backed this up reflecting the power of 'hot knowledge' (Ball and Vincent 1998) and gossip in rural communities (Parr et al., 2004).

\footnotetext{
${ }^{1}$ Church of England schools are divided into two categories: voluntary controlled and voluntary aided. The Local Authority maintains and is the school's admissions authority for voluntary controlled schools, such as Fieldsend. The Church has less influence over voluntarily-controlled schools than voluntarily-aided schools, with regard to school ethos and admissions. The surplus of primary-school places means that here, unlike in other counties, faith is not currently used as a criterion for school admissions.
} 


\subsection{Greenthwaite Community School}

Greenthwaite School is an infant and junior school for 4-11 year olds. The children are divided into two classes. Pupil attainment on entry is at the 'expected level' (Ofsted, 2001b). The school has two classrooms, an office for the headteacher and a small office/kitchen for the secretary. There are very few services within the village, other than the school, village hall and church, and since the Victorian school building is located on the village green the school appears visually to be 'at the heart of the community'.

The school is renowned locally for its high academic standards and the excellent art, drama and music teaching the school provides. It received national media attention for winning a prestigious national art competition which provided wide exposure to potential consumers. Headteacher Bill believes that the school's 'outstanding' reputation is crucial to its survival: 'if I relied on the children from Greenthwaite there would be seven children in school'. Bill is aware that, by specifically targeting parents from out-of-catchment, he is attracting parents who consider Greenthwaite to be 'superior' [Bill's judgement] to their local school and recognises that this choice costs the parents 'time, transport and commitment'.

\subsection{Marshland Community School}

Marshland School is an infant and junior school for 4-11 year olds. The school has two classrooms, a classroom/library, a hall, an office, a staff-room, a kitchen (school meals are cooked on the premises), a playground and playing fields. The children are divided into three classes. Pupil attainment on entry is 'slightly below the expected 
level' (Ofsted, 2000b). The school was built in the 1960s on the edge of the village next to what was originally a small council-housing estate. The village contains a mix of houses including barn conversions, modern detached houses, small terraced cottages and housing-association homes. Village services include a pub, a church, a chapel and a baker's shop.

The school has a reputation for working closely with the local community and was the first within the area to offer extended childcare with a breakfast club and an afterschool club and an on-site nursery. Headteacher Rebecca recognises that this gave the school a marketing advantage because, 'there are certainly some parents who have deliberately chosen the school because of the care that we provide'.

In the following section through the themes of lifestyle and loyalty we explore the complexity of parents' choice-making with reference to their capital and their habitus in order to understand how resources and values informed the choice-making process for this set of parents.

\section{Parents making choices: the familiar and the unknown}

For some parents school choice is not a complicated process, being governed by familial ties to their local catchment school. Local parent Jenny works part-time as a clerk cashier in the family business and is a parent helper at Greenthwaite School; her husband is a company director and also a parent governor at the school. Their two children both attended their nearest school, Greenthwaite, and here Jenny explains how family habitus affected her choice decision: 'There isn't another school in the area I would have chosen; I have family in the village and both my nieces have been 
educated here'. For some parents the attractiveness of the village school is linked to the myth of the 'rural idyll' (Valentine, 1997) and, as Woods (2005, p.13) points out, the myth has been responsible for encouraging in-migrants to move to the countryside. Several newcomer parents (who eventually chose out-of-catchment) expressed difficulties in actually finding out about the schools, describing the process as long and convoluted. Paula remembered that she was given information about only the catchment school: 'We weren't told about another school' and Samantha said, 'I didn't even know there was a school here; I was so new to the area'. The newly arrived migrants lacked local knowledge about the surrounding schools and therefore needed to make an effort in order to make their choices.

\subsection{Lifestyle and school choice}

For several newcomer parents school choice was linked to lifestyle and the decision to migrate to the countryside. Karl, a former teacher and newcomer from Germany, said: 'My wife and I needed a property with some land for horses...then we found Greenthwaite...without the school we would not in fact have moved here'. Karl was keen that his children should attend their nearest school because it was what he had done when he was a child, 'we walked to school...my parents never ever would take us in the car to school'. Fortunately, Karl and his wife had the economic capital to buy a house in a village, which the school secretary said 'was an unusual occurrence for a young family' because of the high price of houses. Nevertheless, walking to school was not Karl's only priority; school size was also an issue. Karl preferred small schools because his experience as a teacher was that, 'the smaller the classes, the easier problems can be sorted out'. What Karl specifically liked about Greenthwaite was, 'the care they get here, the personal attention'. Karl is like the 
stereotypical, high-wealth urban parent who buys into the catchment of the 'right' school and 'right' for Karl, an education-insider, is influenced by his habitus such that he preferred to send his children to a very small local school.

Rural primary schools are often perceived to be distinctive and better because of their small size and caring family ethos (Local Government Association, 2000). Indeed the wider research project on which this paper draws showed that the three factors - small school size, caring school ethos and one-to-one attention - were frequently mentioned by the newcomer parents as the variables that attracted them to choose a rural school, allowing the parents to take into account particular characteristics of their children and to match them to the schools (Moser, 2006). Colin and his wife (who is a general practitioner) bought a four-bedroomed, detached house in Fieldsend village, which headteacher Alison says, 'is becoming quite an elite place'. Former secondary-school teacher and newcomer Colin said his five-year-old son, James, had dyslexia and he wanted him to attend a small school so that James would have extra help from the staff. However, Colin considered Greenthwaite with its two-classes to be 'too small' and that the relatively larger six-class school at Fieldsend would be better suited for James. Colin said, 'I think it's good that everyone knows everyone. All the kids know the parents, the staff; it's just size and I think that's the biggest plus point of the school'. School size also affected Colin's long-term thinking with regard to secondary school choice; Fieldsend is in the catchment area of a small secondary school in Fayretown. Moreover, here we see how education-insider Colin was also affected by his own schooling: 
I was keen we would be in the Fayretown secondary school catchment area...I went to a fairly small secondary school and I've always felt that small schools have got huge advantages. (Colin, Fieldsend School, catchment)

Colin, like Karl, is buying into the catchment of his preferred school but in this case the 'right' school for Colin extends from the primary into the secondary sector. Hence Colin's plans for his son's schooling are typical of the middle-class, long-term planning discussed by Gewirtz et al. (1995). And similarly to Karl, choice for Colin is also influenced by habitus and his personal experience of attending a small school.

However, not all the newcomers could afford to buy into the village of the school of their choice. Louise and her husband, who is a self-employed fine artist, migrated from the city to Fayretown, a small rural town approximately seven miles away from Fieldsend. Louise, like a number of parents who were interviewed, was concerned that her child 'would get lost at the back of a class of 30 pupils' and so she chose Fieldsend rather than one of the larger schools in Fayretown:

...he was very shy and I just thought he might get lost at the back of a big class. I could tell he was bright...I just felt that in a big class if you can do the work you might be left to it more, rather than being perhaps pushed a bit further. And also I thought it would combat his shyness which I think has worked here because I think being in that just smaller group has helped. (Louise, Fieldsend School, out-of-catchment)

Nevertheless, choosing the somewhat smaller village school requires a time-space flexibility from full-time, homemaker Louise because it involves a twice-daily, 
fourteen-mile commute which, if both of her children attend Fieldsend through to the end of their primary schooling, will extend over ten years. Research by Little and Austin (1996) shows that mothers consider the countryside to be a safer place than the city to bring up their children. Sian also moved from the city to the countryside to provide her two children with what she referred to as 'a rural lifestyle'. Sian is a selfemployed business consultant with an MSc in Community Education and her husband is a former Steiner schoolteacher. They were keen to find a school with small class sizes and so they rejected the nearest school, whose classes averaged 30 pupils, and opted for the 'very small' out-of-catchment Greenthwaite:

The education system in Britain starts kids too young...our view is that kids up to seven should be playing and hanging out. When we moved here, my son was rising seven and hadn't been to school so we thought there is no point in putting him with 30 children where he'll be with age-peers but way behind in terms of the basic stuff, although ahead in other things...So we thought we'd look around and we came down for a day and sat in and thought a) they are robust enough to cope and b) he is not going to be so shown up because he is going to be in a class with four, five and six-year olds. (Sian, Greenthwaite School, out-of-catchment)

However, the daily commute from one village to another has resulted in Sian feeling like 'a fish out of water' at the school gate. Her ideal is that the children walk to school but in order to provide them with the education of her choice she drives them to a school seven miles from their home. Sian has the resources to enable her to exercise choice. Firstly, the family had the economic capital to relocate from the city to the countryside. Secondly, she and her husband have high levels of educational 
capital, which gives them the confidence to choose the school they believe will best suit their children. Thirdly, since both parents are self-employed they have flexible working hours giving them time to commit to the twice-daily, fourteen-mile school run.

Newcomer and full-time homemaker Samantha also committed herself to a twicedaily twelve-mile school run rather than opt for her local school. Samantha's husband is a solicitor and they recently moved to the countryside from London. Samantha has the time to commit to the school run which sometimes extends to three round trips in one day when she returns to school in the evening to support school events such as the weekly aerobics class for staff and parents. Her experience of both the private and the state sector in London has convinced her that the daily school run is 'worth it':

...moving up from having to fight for places in London you are used to having to drive further to get to a decent school. It takes me twenty-five minutes to drive here and twenty-five minutes to drive home. They've got more than the state school in London had facility wise... I just can't fault it compared with what I've come from with private schools and paying fees and then coming here; it's incredible... (Samantha, Marshland School, out-of-catchment)

Like Sian who 'looked around' before making her choice, Samantha, describing herself as a 'ruthless, pushy parent', visited four schools before opting for Marshland. Nevertheless, schools with ten or fewer pupils in Year 6 do not have their Key Stage 2 SATs (Standard Assessment Task) results published in the league tables to protect individual pupils from identification (DfES 2004) and so Samantha turned to the schools' Ofsted reports: 
I was looking at their 'areas for improvement'; I was looking for the faults first and then I read the summary. Ofsted are always quite pleasant about the schools, it just depends on what adjective they use. (Samantha, Marshland School, out-of-catchment).

In addition to her detailed examination of the reports, Samantha also used the skills she learned from her own 'determined' mother whom she described as 'trawling around' to find a school for her after she had failed the 11+. Samantha is concerned with the extrinsic value which educational qualifications bring and wants her son to attend the local selective grammar school. Here she explains how her own experiences together with her economic capital have affected her approach to her son's situation:

I'd never seen a paper until the day of my $11+$ so we weren't prepared ...I'm coaching him in the evenings and really doing my best to get him there; I spend a fortune on those past papers. (Samantha, Marshland School, out-ofcatchment)

It is clear that the choice process Samantha engaged with took a great deal of time and effort, something that Sian also invested in her choice of schools. But significantly these two parents chose different schools that are only three miles apart. Samantha did not consider Greenthwaite because it was 'too small' whereas Sian specifically wanted a 'very small school'2. Samantha consulted the Ofsted reports but Sian relied more upon her educational capital and her husband's 'insider' knowledge of the system. Within the typology of choosers both Samantha and Sian are middle-class

\footnotetext{
${ }^{2}$ Schools with 50 or fewer pupils are described by Ofsted as 'very small'.
} 
and skilled but they are operating with differing values illustrated by the different ways they went about the choice process. Samantha's ultimate goal is that her son will pass the entrance examination to the local selective school whereas Sian's goal is for her children to attend a school that pays attention to the expressive side of the child 'despite the National Curriculum'. One of the things she likes about Greenthwaite is that in her opinion the pupils 'are not sweating away worrying about the SATs too much' whereas Samantha believes that it is important for her son to spend an extra hour each day on SATs revision in order 'to earn TV'. The difference between these mothers is that Samantha is a skilled 'managerial' middle-class chooser (Vincent, 2001) who places her trust in public measures of accountability such as Ofsted reports. In contrast, Sian relies on her own education capital and her husband's 'education-insider' status so that Sian is in fact a skilled 'professional' middle-class chooser (Vincent, 2001).

\subsection{Loyalty and school choice}

For the newcomer parents, who can afford to buy locally and for those parents who live out-of-catchment and can afford the time and cost of the daily school run, choice appears to be advantageous. However, not all of the participants agreed that parents should have that choice. The general response from the local parents was that parents should support their catchment school and that not to do so was divisive to the local community and could jeopardise the survival of the school.

Local parent Jenny saw the school offering a key service to the community, 'I think if the village was to lose the school the village would die really because it is the hub of the village'. Although Jenny understands that the school must draw out-of-catchment 
pupils to maintain the pupil roll, she gets angry that the parents from out-of-catchment do not make as much effort to support the school as the locals:

They'll do a Cheese and Wine and it's getting to the point where it's not supported as well from some of the parents that live out of the area but you'll guarantee it will be mostly village people that will support it which annoys me cos I think, 'well, we're getting the village people coming in and it's your school, isn't it? But that's how society is going now; some people just want their children educated. (Parent Jenny, Greenthwaite, catchment)

Raymond, who owns a local farm, said that when his primary school closed, 'it affected the community... it knocks the stuffing out of a village because the school is the central thing'. Raymond subsequently attended his new catchment school at Marshland, as have his three children. When the school received a poor Ofsted report in 1997 Raymond was by this time a parent governor and determined to work towards improving the school to ensure its survival. Raymond was aware, as were many of the local parents from the three schools in the cluster, that if pupil numbers fell, small schools were vulnerable to closure and he said this about choice:

It is good, but it isn't good either cos if a school sounds as if it's in trouble, everybody gets on the grapevine 'oh don't send your kids there, they're in big trouble'. It almost lets people run away. (Raymond, Marshland School, catchment)

Raymond felt that parents should support their local school by helping to solve the problems rather than 'jump ship' as newcomer Paula did when she moved her son from Marshland to nearby Greenthwaite following the school's 'poor' 1997 Ofsted 
report. But, as a newcomer, Paula had little allegiance to the locale and she was driven by her personal needs for her son and she said, 'I'd heard that things weren't going right at Marshland' and so she removed him from the school. However, Raymond felt a strong loyalty to his local school, Greenthwaite, and he wanted to preserve it for the rural community. In fact several participants at Marshland made reference to 'the parent' who had 'jumped ship' and it was obvious that tensions were still running high amongst the locals who were angry that management consultant Paula had moved her son to an out-of-catchment school.

Newcomer Samantha also experienced ill feeling because she chose out-of-catchment and said, 'In the village I was labelled quite snobby and a lot of people didn't talk to me for a long time because I hadn't sent my children to the local school'. But having come from London Samantha said she was 'used to having to fight for everything' and her reaction to the people who opted for the nearest school was that they were taking 'the easy option'. Newcomer Kate believes that the local parents take 'the easy option' because of their perception of travel distance:

You find in talking to the local people who've been born and bred here, that if you travel ten miles out of the area they are absolutely amazed... Some people have not been out of the county; they've married locally, all their family is local. I travel five hours to visit my mother but these people have got their parents in the village... and so, yes, if they wanted to move schools, travelling to do so is just not considered. It's got to be their local and that's it. (Kate, Marshland School, catchment)

Full-time homemaker Kate has a BA (Hons) in English and Visual Arts and is married to an industrial manager; after several job-related house moves the family finally 
settled in the village of Marshland. Although Kate's daughter attends the local school Kate has little allegiance to Marshland saying that she would 'do whatever it took' to achieve her daughter's preferred choice, whether this was in- or out-of-catchment. Furthermore, she had little patience with 'moaning' parents who, she said, should 'get up and march on their feet'. Kate clearly lacks an understanding of the barriers, such as transport and time costs involved for some parents in realising school choice. In contrast local parent and part-time farmer Margaret was relieved when her sons moved from nursery to their nearest school two miles away saying, 'I found it a trek having to go five and a half miles to nursery'.

Nevertheless, not all of the local parents sent their children to the nearest school. Some locals (particularly those from Fayretown) chose an out-of-catchment school over issues related to bullying, unhappiness or a fall in school standards. Several parents described the morning school run with parents driving in and out of school catchment areas. Natalie said, 'I pass them every morning; I'm going this way and they're going that way". Natalie is a local mother who chose out-of-catchment because at the time her local school was experiencing difficulties, 'the headmaster was in and out and had a nervous break-down so there was no real focus there'. During her own primary school years Natalie attended an out-of-catchment primary school because her family moved house and rather than change schools Natalie commuted each day. Choosing a school other than her local one therefore did not seem such an unusual decision to make for her children. Like the newcomer parents described earlier who chose out-of-catchment, Natalie was a full-time homemaker with her own car and she had the transport and the time to make a choice for her daughters. If her youngest child remains at Fieldsend School until the move to the 
secondary sector then Natalie will have driven from her local community to the school community for fourteen years.

Although some local parents thought that choice was divisive, choice for parents like Natalie had its advantages. However, for local parents like Jenny and Raymond, the school not only offers a vital service to the community it also represents a symbol of their community identity (Forsythe, 1984) and both parents were loyal and keen to work to support their local school. Nevertheless, as we see with newcomer parents like Paula, Samantha and Kate, the market-driven education system encourages parent consumers to be motivated by self-interest (Gewirtz et al., 1993). Duty to one's child and loyalty to the local school (as a symbol of the wider community) are one and the same for some parents. For others, the individual and the collective are in opposition, with family interests outweighing community interests.

\section{Conclusion}

This paper demonstrates some of the complexities of the school choice process and shows how choice is valued differently by different parents living in rural areas. School choice for some parents was based on one dominant factor; for others it was a combination of factors. For example, some parents chose the local, catchment school because they wanted their children to walk to school; some chose it because of their family ties with the school and others out of a sense of duty to support the local community. However, for those parents who did not feel that their nearest school was the 'right' school, choice involved daily commuting to a more distant school, incurring costs that required a gendered time-space flexibility, since it was mostly the 
mothers who were involved in the school run. Nevertheless, constraints of time and money meant that it was a choice available to some parents more than others.

The urban, parental-choice literature suggests that it is the dominant middle-class parents who have the most spatial power to operationalise the mechanism of parental choice. This paper shows that this is played out in the rural, primary-school market place by those who can afford the cost and the time of the daily commute or by the parents who can afford to move house so that the 'right' school became their local school. Nevertheless, as we have shown in this paper, social class status has some predictive power within the school choice process (particularly when Lowdale School is compared with the other three studied here) but there are other factors that also come into play; choice is in fact multi-dimensional. For this reason we utilised Bourdieu's relational concepts of capital and habitus to help us capture the complexities involved in the choice-making process for parents. Parents not only brought their economic capital into the process but also their cultural capital which includes their educational qualifications and most importantly for some, their 'insider' knowledge of the education system. The parents with the most choice were the parents with the most amounts of economic and cultural capital.

However, choice for the majority of the parents in this study was also tempered by their childhood experiences. Some parents like Karl wanted to reproduce their schooling, involving criteria such as small and local, whereas some parents, like Samantha, wanted their children to have a better education than they had experienced. There were also parents who thought in the short-term so that choice of primary school was an end in itself and then there were the long-term strategists such as Colin, 
who thought beyond the primary and on to the secondary sector. There were many ways in which a school could be the 'right' one with parents such as Sian and Margaret, choosing the same school for different reasons. Sian chose Greenthwaite because of its small size and school ethos whereas Margaret chose it because it was her nearest school. Indeed the process was one of equifinality in which the same outcome was reached by parents for different reasons. In order therefore to highlight the various processes rather than the outcomes we studied the parents' personal childhood and work experiences through the embodied concept of habitus and considered how habitus affected the choice process.

For some local parents, like Natalie, her own childhood experience of attending an out-of-catchment school spurred her on to look for an alternative school when her local school was experiencing difficulties. Nevertheless, for the majority of local parents like Raymond, school choice included an emotional commitment to the rural community which involved supporting the local school. However, the study shows that not all of the participants believed that choice was necessarily good; some saw it as in fact divisive to the community. The newcomer parents had less commitment to place and therefore were more likely to shop around than the local parents who had a stronger allegiance to support their local school. In an urban environment it is perhaps less obvious when parents do not support their local school. However, in a rural location, where there are fewer schools and the boundaries surrounding rural communities are more visible (Cohen, 1982), it is more obvious when parents do not choose the local village school. This leaves those 'exercising their right to choose' or 'defecting' open to criticism, particularly from the local parents. 
The more recent approach to parental choice connecting social class fractions, lifestyle and locality (Vincent, 2001; Vincent et al., 2004; Ball and Vincent, 2005) suggests that for families with school-age children lifestyle choice includes school choice and that this is connected to locality. However, the research in this paper shows that this is too simple; rural lifestyle for the newcomer parents is not enough and not place specific. It has to be the 'right' rural school. Certainly current rural migration literature suggests that people who opt for a rural lifestyle also wish to join the rural community (Cloke et al., 1995), which one would presume includes supporting the local school, but as McDowell (2006) has also shown, with the urban middle-classes, lifestyle is not necessarily place specific. Some of the newcomer parents and some of the local parents within this study engaged in a daily migration from one rural community to another in order to provide their children with their preferred school choice suggesting that educational style and reproducing social advantage were more important to these parents than community loyalty.

Nevertheless, the newcomer parents more often had less allegiance to place than longer-term residents, and hence to the symbolic position that the school holds within the rural community where they lived. Allegiance to place has become less important in school choices amongst newcomers as a result of the marketisation of education. Allegiance to place is less enforced by rigid catchment area policies and now has to be won by schools from those parents who have the economic and cultural capital to exercise real choice. The reality is that the three schools in this study are working within a local arena where there is an increasing trend of falling pupil numbers within the county. So every pupil attracted from out-of-catchment to another rural primary school moves the catchment school closer to the size threshold for closure. The 
policy of school choice encourages parents with resources to drive their children from one village to the next in their quest to find the 'right' school. However, as our study shows, it is more difficult for parents to fully engage with their chosen rural school when the school is not their nearest. Moreover, driving out-of-catchment increases 'school-run miles' when we are being asked to reduce our carbon footprint (DfT, 2004) and when children are being encouraged to walk and cycle to school for health reasons (NICE, 2009). Future research might examine changes in parents' choices as travel costs increase and the achievements and reputations of individual schools wax and wane.

\section{Acknowledgements}

Our thanks go to the staff, pupils, parents and volunteers at the three schools for agreeing to take part in the research. Marion also wishes to thank the ESRC for funding her postdoctoral fellowship (PTA-026-27-1547). And finally, thank you to Dr. Jo Armstrong and to Prof. Andrew Sayer for their helpful comments. 


\section{References}

Archer, L., and Francis, B. (2006) Challenging classes?: exploring the role of social class within the identities and achievement of British Chinese pupils. Sociology 40, 29-49.

Archer, M. S. (2000) Being Human: The Problem of Agency. Cambridge: Cambridge University Press.

Ball, S. J. (1993) Education markets, choice and social class: the market as a class strategy in the UK and the USA. British Journal of Sociology of Education 14 (1), 3-19.

Ball, S. J. (2003) Class Strategies and the Education Market: The Middle-Classes and Social Advantage. London, Taylor and Francis.

Ball, S. J. and Vincent, C. (1998) 'I heard it on the grapevine': 'Hot' knowledge and school choice. British Journal of Sociology of Education 19(3), 377-400.

Ball, S. J. and Vincent, C. (2005) The 'childcare champion'? New Labour, social justice and the childcare market. British Educational Research Journal 31(5), $557-570$.

Ball, S. J., Vincent, C., Kemp, S. and Pietikainen, S. (2004) Middle class fractions, childcare and the 'relational' and 'normative' aspects of class practices. The Sociological Review 478-502.

Bell, A. and Sigsworth, A. (1987) The Small Primary School: A Matter of Quality. East Sussex, The Falmer Press.

Bourdieu, P. (1977) Outline of a Theory of Practice. Cambridge, Cambridge University Press. 
Bourdieu, P. (1984) Distinction: A Social Critique of the Judgement of Taste. London, Routledge and Kegan Paul.

Bradley, S., Crouchley, R., Millington, J. and Taylor, J. (2000) Testing for quasimarket forces in secondary education. Oxford Bulletin of Economics and Statistics 62(3), 357-390.

Bradley, S., Johnes, G. and Millington, J. (2001) The effect of competition on the efficiency of secondary schools in England. European Journal of Operational Research 135, 545-568.

Butler, T. (1997) Gentrification and the Middle Classes. Aldershot, Ashgate.

Butler, T. and Hamnett, C. (2007) The geography of education: introduction. Urban Studies 44(7), 1161-1174.

Butler, T. and Robson, G. (2003) Plotting the middle classes: gentrification and circuits of education in London. Housing Studies 18, 5-28

Cloke, P., Phillips, M. and Thrift, N. (1995) The new middle-classes and the social constructs of rural living. In Social Change and the Middle-Classes, pp. 220238, Butler, T. and Savage, M. (eds). London, UCL Press.

Cloke, P. and Thrift, N. (1990) Class and change in rural Britain. In Rural Restructuring: Global Processes and their Responses, pp. 165-181, Marsden, T., Lowe, P. and Whatmore, S. (eds). London, David Fulton.

Cohen, A. P. (ed) (1982) Belonging: Identity and Social Organisation in British Rural Cultures. Manchester, Manchester University Press.

Crozier, G., Reay, D., James, D., Jamieson, F., Beedell, P., Hollingworth, S. and Williams, K. (2008) White middle-class parents, identities, educational choice and the urban comprehensive school: dilemmas, ambivalence and moral ambiguity. British Journal of Sociology of Education 29(3), 261-272. 
DfE (Department of Education) (1992) Choice and Diversity: A New Framework for Schools (Cm. 2021). London, HMSO.

DfES (Department for Education and Skills) (2004) 2003 Primary School (Key Stage 2) Performance Tables. http://www.dfes.gov.uk/performancetables/primary_03/p4.shtml (Accessed 22/04/04).

Defra (Department for Environment, Food and Rural Affairs) (2004) Review of the rural white paper - Our countryside: the future. London, Defra Publications.

DETR (Department for Environment, Transport and the Regions) (2000) Our Countryside: the Future - a fair deal for rural England (Rural White Paper, Cm. 4909). London, HMSO.

DfT (Department for Transport) (2004) Walking and cycling: an action plan http://www.dft.gov.uk/pgr/sustainable/walking/actionplan/ (Accessed 05/11/09).

Dovey, K. (2005) The silent complicity of architecture. In Habitus: A Sense of Place $2^{\text {nd }}$ ed., pp. 283-296, Hillier J. and Rooksby, E. (eds). Aldershot, Ashgate.

Forsythe, D. (1984) The social effects of primary school closure. In Locality and Rurality: Economy and Society in Rural Regions, Bradley, T. and Lowe, P. (eds). Norwich, Geo Books.

Francis, B. and Archer, L. (2005) British-Chinese pupils' and parents' constructions of the value of education. British Educational Research Journal 31(1), 89-108.

Gewirtz, S., Ball, S. J. and Bowe, R. (1993) Values and ethics in the education market place: the case of Northwark Park. International Studies in Sociology of Education 3(2), 233-253. 
Gewirtz, S., Ball, S. J. and Bowe, R. (1995) Markets, Choice and Equity in Education. Buckingham, Open University Press.

Goldring, E. B. and Hausman, C. S. (1999) Reasons for parental choice of urban schools. Journal of Education Policy 14(5), 469-490.

Gulson, K.N. and Symes, C. (eds) (2007) Spatial Theories of Education: Policy and Geography Matters. New York, Routledge.

Hansom Thiem, C. (2008) Thinking through education: the geographies of contemporary educational restructuring. Progress in Human Geography 1-20.

Le Grand, J. (1991a) Quasi-markets and social policy. Economic Journal 101, 12561267.

Le Grand, J. (1991b) Liberty, equality and vouchers. In Empowering the Parents: How to Break the Schools Monopoly, pp. 77-90, Green, D. G. (ed). London, IEA Health and Welfare Unit.

Limb, M., and Dwyer, C. (eds) (2001) Qualitative Methodologies for Geographers: Issues and Debates. London, Arnold.

Little, J. and Austin, R. (1996) Women and the rural idyll. Journal of Rural Studies 12(2), 101-111.

Local Government Association (2000) Education in Rural Communities: Report by the Local Government Association Education and Lifelong Learning Working Group. http://www.lga.gov.uk/Documents/Publication/RuralIssues.PDF (Accessed 19/08/05).

Mahar, C. (1990) 'Pierre Bourdieu: the intellectual project'. In An Introduction to the Work of Pierre Bourdieu: The Practice of Theory, R. Harker., Mahar, C. and Wilkes, C. (eds). Hampshire, Macmillan Press. 
Massey, D. (1995) Reflections on gender and geography. In Social Change and the Middle Classes, pp. 330-344, Butler, T. and Savage, M. (eds). London, UCL Press.

McDowell, L., Ward, K., Perrons, D., Ray, K. and Fagan, C. (2006) Place, class and local circuits of reproduction: exploring the social geography of middle-class childcare in London. Urban Studies 43(12), 2163-2182.

Moser, M. (2006) Rural primary schools: mapping conflict between the community and the market, $\mathrm{PhD}$ Thesis. Department of Educational Research, Lancaster University.

NICE (National Institute for Health and Clinical Excellence) (2009) Promoting physical activity for children and young people. http://guidance.nice.org.uk/PH17 (Accessed 05/11/09).

Ofsted (Office for Standards in Education) (2000a) Ofsted inspection report for 'Fieldsend' C of E School. http://www.ofsted.gov.uk/ (Accessed 08/04/2004).

Ofsted (2000b) Ofsted inspection report for 'Marshland' Community School. http://www.ofsted.gov.uk/ (Accessed 08/04/2004).

Ofsted (2001a) Ofsted inspection report for Local Education Authority. X County Council: from the World Wide Web (Accessed 09/10/05).

Ofsted (2001b) Ofsted inspection report for 'Greenthwaite' Community School. http://www.ofsted.gov.uk/ (Accessed 08/04/2004).

Parr, H., Philo, C. and Burns, H. (2004) Social geographies of rural mental health: experiencing inclusions and exclusions. Transactions of the Institute of British Geographers 29(4), $401-419$. 
Reay, D. (1995a) 'Using habitus to look at "race" and class in primary school classrooms'. In Anti-racism, Culture and Social Justice in Education. Griffiths, M. and Troyna, B. (eds). Stoke-on Trent, Trentham Books.

Reay, D. (1995b) "They employ cleaners to do that": habitus in the primary classroom. British Journal of Sociology of Education, 16(3), 353-371.

Reay, D. (1996) Contextualising choice: social power and parental involvement. British Educational Research Journal 22(5), 581-595.

Reay, D. (2004) 'It's all becoming a habitus': beyond the habitual use of habitus in educational research. British Journal of Sociology of Education 25(4), 431444.

Reay, D. and Ball, S. J. (1998) "Making their minds up": Family dynamics of school choice. British Educational Research Journal 24(4), 431-448.

Reay, D., Hollingworth, S., Williams, K., Crozier, G., Jamieson, F., James, D. and Beedell, P. (2007) 'A darker shade of pale?' Whiteness, the middle classes and multi-ethnic inner city schooling. Sociology 41(6), 1041-1060.

Reay, D. and Lucey, H. (2000) Children, school choice and social differences. Educational Studies 26(1), 83-100.

Ribchester, C., and Edwards, B. (1999) The centre and the local: policy and practice in rural education provision. Journal of Rural Studies 15(1), 49-63.

Savage, M. (2000) Class Analysis and Social Transformation. Buckingham, Open University Press.

Smith, D. and Higley, R. (2008) The 'other' dimensions of contemporary rural gentrification. Paper presented at the Royal Geographical Society with IBG Annual International Conference. RGS London, 27-29 August. 
Taylor, C. (2001a) Hierarchies and 'local' markets: the geography of the 'lived' market place in secondary education provision. Journal of Education Policy 16(3), 197-214.

Taylor, C. (2001b) The geography of choice and diversity in the 'new' secondary education market of England. Area 33(4), 368-381.

Taylor, C. (2002) Geography of the 'New' Education Market: Secondary School Choice in England and Wales. Aldershot, Ashgate.

Urry, J. (1995) A middle-class countryside? In Social Change and the Middle Classes, pp. 205-219, Butler, T. and Savage, M. (eds). London, UCL Press.

Valentine, G. (1997) A safe place to grow up? Parenting perceptions of children's safety and the rural idyll. Journal of Rural Studies 13(2), 137-148.

Vincent, C. (2001) Social class and parental agency. Journal of Education Policy 16(4), 347-364.

Vincent, C., Ball, S. J. and Kemp, S. (2004) The social geography of childcare: making up a middle-class child. British Journal of Sociology of Education 25(2), 229-244.

Warrington, M. (2005) Mirage in the desert? Access to educational opportunities in an area of social exclusion. Antipode 796-816.

Willms, J. D. and Echols, F. (1992) Alert and inert clients: the Scottish experience of parental choice of schools. Economics of Education Review 11(4), 339-350.

Woods, M. (2005) Contesting Rurality: Politics in the British Countryside. Aldershot, Ashgate.

Williams, J. (2008) United we stand: a soft federation model for small primary schools www.ncsl.org.uk (Accessed 23/07/09) 
Table 1: Parent Participants

\begin{tabular}{|c|c|c|c|c|c|c|}
\hline \multicolumn{7}{|c|}{ Fieldsend C of E School } \\
\hline Participant & \begin{tabular}{|c|}
$\overline{\tilde{g}}$ \\
$\stackrel{9}{9}$
\end{tabular} & 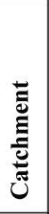 & 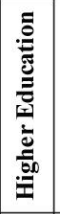 & Occupation & Partner's Occupation & Notes \\
\hline Cheryl & $\checkmark$ & $\checkmark$ & & Beauty Therapist & Agricultural Contractor & \\
\hline Colin & & $\checkmark$ & $\checkmark$ & Full-time Homemaker, Former Teacher & General Practitioner & Parent Governor \\
\hline Janet & $\checkmark$ & & & Full-time Homemaker, Former HGV Driver & HGV Driver & \\
\hline Natalie & $\checkmark$ & & $\checkmark$ & Full-time Homemaker & Manager & Parent Helper \\
\hline Sally & & $\checkmark$ & & Full-time Homemaker & Company Director & Parent Helper \\
\hline Louise & & & $\checkmark$ & Full-time Homemaker & Artist & Parent Helper \\
\hline
\end{tabular}

\begin{tabular}{|c|c|c|c|c|c|c|}
\hline \multicolumn{7}{|c|}{ Greenthwaite Community School } \\
\hline Participant & 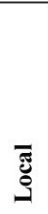 & 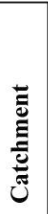 & 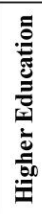 & Occupation & Partner's Occupation & Notes \\
\hline Jenny & $\checkmark$ & $\checkmark$ & & Cashier Clerk & Company Director & Parent Helper \\
\hline Karl & & $\checkmark$ & $\checkmark$ & Self-employed Translator, Former Teacher & Horse Masseuse & \\
\hline Margaret & $\checkmark$ & $\checkmark$ & $\checkmark$ & Part-time Farmer & Farmer & Parent Governor \\
\hline Paula & & & $\checkmark$ & Part-time Hotel Manager & International Loss Adjuster & Parent Governor \\
\hline Sian & & & $\checkmark$ & Self-employed Consultant & Cabinet Maker & \\
\hline Victoria & & & $\checkmark$ & Self-employed Journalist & Journalist & \\
\hline
\end{tabular}

\begin{tabular}{|c|c|c|c|c|c|c|}
\hline \multicolumn{7}{|c|}{ Marshland Community School } \\
\hline Participant & \begin{tabular}{l|}
$\bar{\delta}$ \\
$\stackrel{g}{\Xi}$
\end{tabular} & 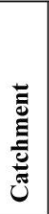 & 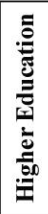 & Occupation & Partner's Occupation & Notes \\
\hline Carol & & & & Breakfast Club Leader, Former Secretary & & \\
\hline Jackie & & $\checkmark$ & & Part-time Accounting & Chef & Chair of Governors \\
\hline Kate & & $\checkmark$ & $\checkmark$ & Full-time Homemaker & Industrial Manager & \\
\hline Kelly & $\checkmark$ & & & Care Assistant & & \\
\hline Pat & $\checkmark$ & $\checkmark$ & & Part-time Cashier & Farm Worker & Chair of Nursery \\
\hline Raymond & $\checkmark$ & $\checkmark$ & & Farmer & School Secretary & \\
\hline Samantha & & & & Full-time Homemaker, Former Secretary & Solicitor & \\
\hline
\end{tabular}


Table 2: School and county council interview participants

\begin{tabular}{|c|c|}
\hline \multicolumn{2}{|r|}{ Fieldsend C of E School } \\
\hline Alison & $\begin{array}{l}\text { Headteacher } \\
\text { Year } 4,5 \& 6 \text { Teacher } \\
2 \text { interviews }\end{array}$ \\
\hline Jill & $\begin{array}{l}\text { Nursery Leader } \\
\text { Early Years Classroom Assistant } \\
2 \text { interviews }\end{array}$ \\
\hline Marilyn & Former Headteacher \\
\hline \multicolumn{2}{|c|}{ Greenthwaite Community School } \\
\hline Bill & $\begin{array}{l}\text { Headteacher/Key Stage } 2 \text { Teacher } \\
\text { (retired art teacher) }\end{array}$ \\
\hline Val & Early Years and Key Stage 1 Teacher \\
\hline \multicolumn{2}{|r|}{ Marshland Community School } \\
\hline Rebecca & $\begin{array}{l}\text { Headteacher and Year } 5 \& 6 \text { (with one } \\
\text { child at the school) }\end{array}$ \\
\hline Beth & $\begin{array}{l}\text { Year } 3 \& 4 \text { Teacher (with two children at } \\
\text { the school) }\end{array}$ \\
\hline Jane & Early Years and Key Stage 1 Teacher \\
\hline Lisa & $\begin{array}{l}\text { Peripatetic music teacher (with one child } \\
\text { at the school) }\end{array}$ \\
\hline \multicolumn{2}{|r|}{ County Council } \\
\hline Andrew & $\begin{array}{l}\text { Local Service Delivery Area Support } \\
\text { Manager }\end{array}$ \\
\hline Elaine & LEA Link Inspector Advisor \\
\hline Jean & $\begin{array}{c}\text { Liberal Democrat County Councillor and } \\
\text { Cabinet Member for Education }\end{array}$ \\
\hline
\end{tabular}


Table 3: The Schools

\begin{tabular}{|c|c|c|c|c|c|c|}
\hline Name & pe & $\begin{array}{l}\text { Pupil Role / } \\
\text { Capacity }\end{array}$ & $\begin{array}{l}\text { Ofsted } \\
\text { Rating }\end{array}$ & $\begin{array}{c}\text { Local } \\
\text { (Out of Catchment) }\end{array}$ & $\begin{array}{l}\text { Free School } \\
\text { Meals }\end{array}$ & $\begin{array}{l}\text { Pupils with } \\
\text { Special Needs }\end{array}$ \\
\hline Greenthwaite & Community School & $24 / 28$ & Outstanding & $7(17)$ & 0 & 0 \\
\hline Fieldsend & Church of England Voluntary Controlled & $47 / 56$ & Good & $20(27)$ & 0 & 0 \\
\hline Marshland & Community School & $49 / 56$ & Good & $39(10)$ & 1 & 9 \\
\hline
\end{tabular}

